\title{
Exploring the Needed Marketing Content and Strategies to Combat the Negative Global Conditions and Promote Nation Branding for the Post COVID-19 Pandemic Period ${ }^{1}$
}

\author{
Dr. Eman M. Negm²
}

Dr. Ahmed M. Elsamadicy ${ }^{3}$

\begin{abstract}
The global outbreak of the COVID-19 pandemic impacted nations and enterprises in the tourism industry. This paper explored how nations can use nation branding during the COVID-19 pandemic to promote optimism in order to stimulate tourism when the peak of the crisis is over. The research pursued to answer the research question: what nation-branding strategies can be used to aid nations in promoting future tourism demand? The research conducted semi-structured interviews with 20 potential tourists from different nations until saturation level was met (people who enjoy to travel and seek to travel once the COVID-19 crisis passes). According to the interviews, nine main themes emerged: citizens are living, buying, and thinking differently; citizens are striving to adapt to a new normal; the COVID19 pandemic reduced-contact channels to get goods/services; the "endless layover" feeling is stirred by the COVID-19 pandemic; consumers want extra reassurance to resume traveling activities; citizens are waiting for indicators beyond lifted restrictions before regularly engaging in traveling to a specific destination; domestic tourism is expected in the coming period; hit the brakes on marketing and promote values of humanity; the virus changed the way people use the Internet, rising in-home media consumption. With these findings, this study provided recommended plans for nation branding to help take the necessary actions to ensure and prepare for the future recovery of the tourism market. Like this, this study contributed practically. In addition, this study developed empirical evidence that contributes knowledge, filling in the academic gap found in literature. Prior scholars and researchers

${ }^{1}$ Received in 30/11/2020, accepeted in 11/1/2021.

${ }^{2}$ Dr. Eman Medhat Negm is currently Associate professor, College of Management \&Technology, Arab Academy for Science, Technology and Maritime Transport (Eiman_Medhat@yahoo.com)

${ }^{3}$ Dr. Ahmed Moussa Elsamadicy is currently Associate Professor, College of Management \& Technology, Arab Academy for Science, Technology and Maritime Transport (asamadicy@aast.edu)
\end{abstract}


had called for empirically-based papers that focus on the impacts of COVID-19 on markets, destinations, businesses, consumers, destination communities, transit zones and tourism transport (Hall and Cooper, 2020).

Keywords: Consumer Behavior - Nation Branding - Social Media - Tourism Marketing.

\section{1- Introduction}

The tourism business is one of the world's largest industries (Negm and Elsamadicy, 2017). Tourism is the idea of people travelling to other locations (domestically or internationally) for leisure, social or business purposes for a limited period of time (Calderwood and Soshkin, 2019). The tourism industry, also known as the travel industry combines several industries in one. Tourism is made up of the support of other industries such as, the hotel industry, hospitality industry, and transport industry. It also includes other businesses that aid in keeping travelers pleased, engaged, occupied, well-appointed to the destination, and equipped with the things they need during their time away from home (Kotler et al., 2014). Thus, the "tourist trade" drives the economies of nations.

Globally, the sector is amongst the world's top employers (UNWTO World Tourism Barometer, 2019). According to UNWTO (2019), their research showed that: "International tourism represents $7 \%$ of total exports and is the world's third-largest export category by earnings, after chemicals and fuels. In Europe alone, tourism generated almost \$410 billion in revenues in 2019 and provided more than 27 million jobs. In short, tourism is central to the global economic machinery".

According to the first comprehensive report on global tourism numbers and trends of the new decade (UNWTO World Tourism Barometer, 2019), it declared that 2019 is the tenth consecutive year of growth in the industry. The report indicated that 1.5 billion international tourist traveled during 2019, internationally. This number indicated a 4\% increase on the previous year (2018). The report also indicated each countries performance in the industry. It expressly showed that the Middle East emerged as the fastest-growing region for international tourism arrivals in 2019, growing double the global average $(+8 \%)$. This growth is noteworthy since the region faced strong recession during the 2011 Arab Spring. Moreover, the report showed Egypt's tourism sector 
sprouted 21 percent in 2019, receiving 13.6 million visitors. This is a significant progress since the drastic cut of global tourists post 2011 political instability (Maged, 2020).

Now in 2020, the Coronavirus (COVID-19) pandemic emerged. COVID-19 is an infectious disease spread by social interactions among people (Lia Van Der Hoek, 2020). According to the UNWTO (2020), the disease has transpired a negative curse on tourism. Statistics have showed that tourism is probably the single biggest economic casualty of COVID-19. The pandemic has led to the suspension of tourism (European Commission, 2020). UN News (2020) indicated that: "96 percent of all worldwide destinations have put into place travel restrictions in response to the pandemic. Some 90 destinations have completely/ partially closed their borders to tourists, while another 44 are closed to certain tourists depending on their country of origin".

In the past, many disasters and tragedies have occurred and damaged the global economy, whether it is political (war, governmental instability, terrorist attacks, etc.), natural causes (tsunami, hurricanes, earthquakes, forest fires, etc.), or financial crises (Glaesser, 2016). In these various events, tourism proved its resilience and ability to lead recovery (Wenjie et al., 2019). However, with the COVID-19 pandemic, there is high uncertainty over how the crisis will unfold. The UNWTO (2020) indicated in a report that the tourism industry has the ability to strength, leading to future recovery. The UNWTO chief announced to the world: "For now, we must be patient and stand ready... By staying home today, we can travel tomorrow. And travelling tomorrow will support jobs, celebrate culture and promote international friendship and understanding."

Kotler and Armstrong (2018) clarified that communication with individuals allows businesses to develop relationship with prospect consumers. The concept of relationship marketing is a vital component to developing cognitive customer loyalty and long-term customer engagement rather than current and shorter-term goals like customer acquisition and individual sales. Thus, as tourism is presently restricted and boarders are closed, this does not mean marketing should discontinue. Nation branding is recommended (Wenjie et al., 2019). Nation branding is seen as a panacea to many nation's problems 
(Aronczyk, 2013). Nation branding can be seen as an important area of research because it influences many different sections of society (economic, political, social or cultural). Nevertheless, researches argue that there are limited researches on the topic (Vaxevanidou, 2017), creating an urgent need for conceptual and theoretical development of the subject. The COVID-19 pandemic may take awhile for the tourism industry vibrancies. However, growth in visibility and engagement among citizens globally is needed for incremental rewards when the crisis is over, making this topic practically important (Kotler, 2020).

The main objective of this paper is to explore how nations can use nation branding during the COVID-19 pandemic to promote optimism in order to stimulate tourism when the peak of the crisis is over. The paper will review prior literature to provide an overview of the phenomenon of nation branding and the current situation of the world during the COVID19 pandemic in order to answer the following main research question: what nation-branding strategies can be used to aid nations in promoting future tourism? This study seeks to answer the following sub research questions: (RQ1) what are citizens' standpoints and perceptions regarding the COVID-19 pandemic impact on their lives? (RQ2) What are the expected tourism behaviors found among individuals? (RQ3) How should businesses promote nation during the post COVID-19 pandemic era?

\section{2- Literature Review}

The COVID-19 turned the world upside down (Kaefer, 2020). Motivation, continuous workflow, and a positive mind are the main objectives now among governments globally. Research indicated that nation branding is a vital technique in order to recover from any crisis that occurs (Aronczyk, 2013). Nevertheless, "legitimate advertising and crass opportunism is thinner than ever in the eyes of the general public" (Beer, 2020, p.1). Therefore, this paper seeks to understand how can a nation promote its country in a favorable manner in front of its citizens in a time of a pandemic, alluring the realm. The following sections review literature to provide clarification of the current COVID-19 situations and the concept of nation branding. 


\section{2-1 The Era of COVID-19}

The people infected by COVID-19 in the world today are over two million; the deaths almost 75 thousand. The pandemic, it is said, originated from Wuhan, China. From China, it spread massively to Asia, Europe, and the United States. The remaining continents have declared restrained casualties as well. Currently, as each day passes, the numbers of infections seem to double every month (UNWTO, 2020).

The UNWTO (2020) released a report of various behaviors governments should enforce among their citizens to try to control the spread of COVID19. Many countries enforced specific comportments, which were obliged by all populations. According to Bill Gates (2020), if people's behavior had not changed, then most of the population would have been infected. By changing behavior (closing doors and promoting isolation), many countries have gotten the infection rate to plateau and start to come down.

Change in behavior during the pandemic is not just due to restrictions from WHO and government policies. According to psychology scholars, when people about a contagious and deadly disease is spreading widely, they change their behavior on their own (Gates, 2020). When people are aware of a pandemic and the risk involved, they usually: "pause what they are doing, become hyper-vigilant, check out the environment more carefully than they normally would and-this is perhaps the most important characteristic of the adjustment reaction-they take precautions that may be excessive, may be inappropriate, and are certainly premature" (Sandman, 2014, p.1). In relation to the COVID-19 pandemic, most people approved not to go to work offices, cinemas, and restaurants or take trips, to avoid getting infected or infecting others in their household (Gates, 2020).

COVID-19 has significantly damaged the economies of countries across the world (European Commission, 2020). Globally, citizens lost their jobs due to mandatory curfews, restrictions of staying at home and social distancing (UNWTO, 2020). Worldwide, the economic cost that has been paid to reduce the infection rate is high (UNWTO, 2020). Entire sectors of the economy are shut down, such as various businesses related to the tourism and sports industries (Gates, 2020). 


\section{2-2 The Concept of a Crisis and the Importance of Media Communication}

COVID-19 pandemic is a global crisis, causing nations to face an era of deprivation and anxiety. A crisis is an occurrence that leads to an unstable and frightening position, affecting certain people or society as a whole (Szczepanski, 2019). This occurrence leads to psychological stress due to the alarming or anxious experience faced among individuals (Bundy et al., 2017). According to research, crisis has several defining characteristics, which are: "specific, unexpected, and non-routine events or series of events that [create] high levels of uncertainty and threat or perceived threat to an organization's high priority goals" (Seeger et al., 1998, p.231). In another research, a crisis is: "the perception of an event that threatens important expectancies of stakeholders and can impact the organization's performance" (Heath, 2012, p.6). This definition can be applied to nations. Thus, a nation is in a crisis if its image does not meet expectations of certain individuals. All nations are in a crisis during the 2020 pandemic.

Rasmussen and Merkelsen (2014) distinguish two types of crises occurring in nations: sudden and ongoing crises. A sudden crisis is sparked by a specific event, while an ongoing crisis is the result of more long-term image issues. Heath (2012) explained that a crisis could be composed of separate events or part of a bigger organizational issue. When it comes to the COVID-19 pandemic, it occurred and spread unexpectedly and rapidly worldwide. Businesses are locking down, and people are urged to stay home, practice social distancing, and vigorously wash their hands. The COVID-19 has made nations anxious about the upcoming eras. No one knows what is to be held in the future (UNWTO, 2020). Thus, it makes this catastrophe as both sudden and ongoing crisis.

Usually during a crisis, the media gets involved. Heath (2012) indicated that news media are influential in the way a crisis is depicted. Accordingly, the organization (in this case nation) will do anything it can to manage the crisis and the communication surrounding it, practicing the concept of nation branding. Kotler and Armstrong (2018) claimed that the media have an influence on how people perceive a place, especially when the coverage is negative. In the context of the COVID-19, 
WHO explained that if the nation begins to reopen its societies, certain precautions should be taken, promoting physical distancing among everyone, and promoting routine cleaning and disinfection and other personal hygiene and preventive measures (UNWTO, 2020). Gates (2020) explained: "it will take a lot of good communication so that people understand what the risks are and feel comfortable going back to work or school. This will be a gradual process, with some people immediately doing everything that is allowed and others taking it more slowly".

\section{2-3 The Concept of Nation Branding}

Kaneva (2011) explained that nation branding, also known as country branding, is a subcategory of place branding; and when it comes to tourism studies, the field terms it as destination branding. In the preceding years, many nations, worldwide, aim to improve their region's image and appellation to influence its economic vitality (Dinnie, 2008). Nation branding is: "the application of corporate marketing concepts and techniques to countries, in the interests of enhancing their reputation in international relations" (Kerr and Wiseman, 2013, p.354). Branding is significant to nations as it aids them to: "attract tourism and investment capital, increase exports, attract a talented and creative workforce, and enhance their cultural and political influence in the world" (Olins, 2005, p.169). According to literature, the concept is a developing field. Scholars in various fields (international relations, humanities, media communication, and marketing) continue their search for a unified theoretical framework.

Keller (2013) explained that the branding process refers to building and managing a brand in order to make their product stand out from competing products. Branding is practiced by countries' governments and private-sector players (Olins, 2005), revitalizing cities and nations to improve their comeback to changes in the market (Kotler et al., 1993). Bolin and Ståhlberg (2010) claimed that the 21st century nation branding focuses on the future of the nation, as opposed to the history and traditions of the nation. Nation branding reflects the: "the sum of people's perceptions of a country across six areas of national competence: exports, governance, tourism, investment and immigration, culture and heritage, and people" (Anholt, 2003, p.186). Therefore, 
Kotler and Armstrong (2018) indicated that it encourages investment and tourism.

When it comes to practice, nation branding is when governments seek self-conscious activities aimed at producing a certain image of the nation state (Bolin and Ståhlberg, 2010). These activities include: "branding and marketing communications techniques to promote a nation's image" (Fan, 2006, p.6). It can be seen as a way of constructing and communicating national identity and building nationalism (Kotler and Armstrong, 2018)

\section{2-4 Marketing and Communicating Strategies During COVID-}

\section{9}

"A brand's relationship with its customers is always important, but it has never been more critical than it is today". In circumstances like the one the world is facing with the COVID-19 pandemic, which are alarming and fear-provoking among citizens: "uncertain and rapidly changing- clarity and reassurance is demanded" (Handley, 2020, p 1). Various entities, governmental and business, need to be close to their people (target consumers and citizens) during upsetting situations (Kotler and Armstrong, 2018). However, research show people are annoyed at being sent marketing emails from companies (Kotler, 2020). According to Handley (2020), "There's a very fine line between being helpful and flogging stuff on the back of a crisis."

With the first time $21^{\text {st }}$ century pandemic, there is no right way to communicate with audience in these uncertain times (Gates, 2020). According to Kotler and Armstrong (2018), communication holds the potential to: “create new, potentially 'better' or more informed, meanings and understandings for all parties involved" (Blichfeldt, 2017, p.15). Communication allows for the accumulating, creating and advancing knowledge (Blichfeldt, 2017). During the COVID-19, citizens are not looking for businesses to sell them products, but to show compassion to the current events. Thus, marketing communication should avoid selling content, taking into consideration content related to fundraising initiatives or monetary donations. Marketing from various entities should engage with people around the world, encouraging them to stay 
indoors for the foreseeable future; and to put a smile on their faces during dark times (Kotler, 2020).

Travel, hospitality and retail are all industries that have cut their media buys these days during the pandemic (Handley, 2020). This should not be the case (Blichfeldt, 2017). Marketing research show that communication should be continuous to consumers, seeking to build long-term relationships during a crisis (Kotler and Armstrong, 2018). It is not sure when the COVID-19 lockdown measures will be relaxed across the globe (UNWTO, 2020). As a result, destination marketers can begin to prepare for recovery, communicating various messages that give optimism in the community until it is safe for people to travel freely again. According to analytics, focusing on local audiences during these days will build the foundation for domestic tourism, which is realistic in a post crisis world (Yu-Chin et al., 2007). Planning communication strategies during chaos and uncertainty is not aimed for immediate rewards (Eli and Ketter, 2017). Communications that will occur during COVID-19 pandemic may take longer to reap rewards. However, growth in visibility and engagement is needed for incremental rewards (Fortune, 2020).

People during crisis are more compassionate, caring, concerned and gentle than before (Coombs, 2009). Thus, marketing and branding a nation during a time of turmoil should emphasize humanity, constructive spirit and community of places - "content that will spread strength and positivity within domestic markets and may encourage natural engagement" (Fortune, 2020). According to Belch and Belch (2018), when entities empathies with key audiences, it will create efficiencies in content production, running efforts on content with purpose; to create once and publish everywhere with a drastic impact. According to the UN (2020), the COVID-19 pandemic: "has affected people all over. BE empathetic. We all need support, compassion and kindness."

During isolation mode, spending time at home means people are shifting towards screens (Gates, 2020). Social media have become an essential tool in the daily practice of individuals, both practitioners and consumers alike (Prisca, 2019). According to Smart Insights (2018), there are 4 billion Internet users and roughly 3 billion social media users worldwide. 
The number of Internet users and their frequency of exposure have increased significantly these days (Kotler, 2020). People are able to do nearly everything with the internet, such as working, studying, shopping, booking, doing researches, communication, etc. These numbers demonstrate the importance of digital presences (Belch and Belch, 2018). Accordingly, when it comes to nation branding and building tourism demand, countries are requesting to be strategically managed in terms of having a strong digital presence to achieve great search results, based on a positive online reputation. "Any information or image about a country, region or city available online can influence the perception of its Place Brand in the real world" (Fortune, 2020). According to the Pew Research Center (2018), 91\% of people trust what they see and read in search engine results. Correspondingly, most individuals see social media channels as a reliable source of information. Thus, using marketing and social media strategies during COVID-19 pandemic is important (Gates, 2020).

This paper seeks to explore how and what content and strategies should marketers adopt to combat negative perceptions and crises in order to repair the tourism industry for the post COVID-19 pandemic period. Previous studies dealing with tourism crises focused primarily on individual case studies, but did not propose a long-term analysis of image restoration efforts throughout the years; nor did they rely on the knowledge that exists in the field of crisis communications, branding, and image repair (Mair et al., 2014; Eli and Ketter, 2017). Thus, the current study includes qualitative content analyses of on qualitative interviews with citizens in order to uncover potential media strategies, events, and marketing initiatives for nation branding.

\section{3- Methodology}

This study uses qualitative research method, seeking an exploratory purpose to gain an in-depth perspective on actions, practices, and circumstances occurring during the COVID-19 pandemic, and how the disease has transpired a negative curse on various leisure activities that citizens used to partake in, such as tourism. Gaining insight and understanding on the present-day pandemic on consumer behavior (a real-world setting view) will allow marketers to develop a 
comprehension on the needed marketing strategies used by governments and nations in order to promote nation branding.

The population understudy are global citizens who enjoy to travel for various reasons (work, health, leisure, education, etc.) as often as possible, suiting their budget and time. The research seeks to ask this target population for their thoughts on what will restore confidence for people to begin traveling once the Covid-19 pandemic finally recedes. The communicated insights will aid practitioners in nation branding and marketing activities to eliminate travel restrictions caused by the pandemic. Purposive sampling (also known as judgmental, selective, or subjective sampling), a non-probability sampling, was undertaken to select the participants in this study. The researchers relied on their own judgment when choosing members of the population to participate in their study, ensuring study eligibility criteria. According to statistics, "Millennials between 23-38 seem to be the age group that travels the most" (CAPMAS, 2019). Thus, the researcher chose this age group, assuming that they may have more financial stability and would not have to juggle travelling with their education or family.

Semi-structured interviews are used in this study. Semi-structured interviewing is the process of using a series of predetermined openended questions to explore the experiences of individuals who know the phenomena (effectively gain in-depth information from participants). This qualitative research approach, through the use of interviews, seeks to investigate the following key areas: (1) what are citizens' standpoints and perceptions regarding the COVID-19 pandemic impact on their lives? (2) What are the expected tourism behaviors found among individuals? (3) How should businesses promote nation during the post COVID-19 pandemic era? Nine questions are asked. Each question supports the attainment of empirical evidence that answers the research question of the current study. Table 1 shows the questions in the interview guide. 
Table 1: Interview Guide

\begin{tabular}{|c|c|}
\hline Research Questions: & Interview Questions \\
\hline \multirow{3}{*}{$\begin{array}{l}\text { (RQ1) what are citizens' } \\
\text { standpoints and perceptions } \\
\text { regarding the COVID-19 } \\
\text { pandemic impact on their lives? }\end{array}$} & $\begin{array}{l}\text { 1. How did your life change when the COVID-19 } \\
\text { pandemic hit your country? Explain. }\end{array}$ \\
\hline & $\begin{array}{l}\text { 2. Will the COVID-19 pandemic permanently } \\
\text { change the way you think and behave? Why or } \\
\text { why not? }\end{array}$ \\
\hline & $\begin{array}{l}\text { 3. What activities do you miss doing and cannot } \\
\text { do because of the COVID-19 pandemic? } \\
\text { Explain. }\end{array}$ \\
\hline \multirow{3}{*}{$\begin{array}{l}\text { (RQ2) What are the expected } \\
\text { tourism behaviors found among } \\
\text { individuals? }\end{array}$} & $\begin{array}{l}\text { 1. Did you have plans to travel before the COVID- } \\
19 \text { pandemic emerged? Do you still have these } \\
\text { plans? Why or why not? }\end{array}$ \\
\hline & $\begin{array}{l}\text { 2. When do you think you will travel again in the } \\
\text { future? Explain your justification }\end{array}$ \\
\hline & $\begin{array}{l}\text { 3. Which countries would you visit during the } \\
\text { post era of COVID-19 pandemic? Why? }\end{array}$ \\
\hline \multirow{3}{*}{$\begin{array}{l}\text { (RQ3) How should businesses } \\
\text { promote nation during the post } \\
\text { COVID-19 pandemic era? }\end{array}$} & $\begin{array}{l}\text { 1. Where and how will you actually travel once } \\
\text { your willing to hit the road again? Explain. }\end{array}$ \\
\hline & $\begin{array}{l}\text { 2. What role, if any, does tourism promotion and } \\
\text { marketing have at a time when the appetite to } \\
\text { travel is low? } \\
\text { (If a nation is to brand itself during the post } \\
\text { COVID-19 pandemic era, what content should it } \\
\text { promote to attract you to the nation) }\end{array}$ \\
\hline & $\begin{array}{l}\text { 3. Which medium is influential these days to get } \\
\text { your attrition? Explain you selection. }\end{array}$ \\
\hline
\end{tabular}

The interviews are conducted in the English language. English is universal language. It is the world's second native language, the formal language in 70 countries. English-speaking countries are accountable for about $40 \%$ of world's total GNP. English can be used everywhere with educated people around the world (Rai, 2019). Before beginning the actual interviews, the researchers conducted a pilot test involving a sample of four interviewees to adjust any mistakes that might have existed in the grammar, word arrangements, sequence of questions, etc. Once the interview guide was adjusted, the actual interviews began. It took place during June and July 2020. The average interview takes around 45 minutes.

In this study, the researchers' obedience to ethical guidelines is critical to safeguard the security, privacy, bias, and integrity of the study 
(Lunnay et al., 2014). The researchers emailed participants about the research study in order to help develop their understanding of the motive and benefits of the study. The email discussed the right to privacy, confidentiality, informed consent, and withdrawal from the study. A written consent form was attached to the email that required signatures and confidentiality agreements before engaging in interviews. After receiving their emails, acknowledging a willingness to participate, the researchers set a zoom meeting according to participants' preferences.

One of the goals of a researcher is to determine the appropriate number of study participants. A smaller number of participants in a qualitative study are a viable option when the study aims to gain in-depth data by interviewing knowledgeable participants, implementing the data saturation approach (Patton, 2015). Data saturation is necessary to ensure the validity of qualitative research (Yin, 2018). Data saturation is met when the data collected does not reveal new information, coding, or themes (Patton, 2015).

Reliability and validity are essential outcomes for a researcher's study. Researchers focus on reliability and validity by using member checking (Patton, 2015). Member checking is the process used by researchers to ensure consistency of what the researcher interpreted from the interviews by requesting that the participants review their summaries of the interviews (Morse, 2015; Yin, 2018). Member checking allows the researcher to validate the interviewing summaries, created from their field notes and audio recordings. Once member checking is complete, the researchers begin the data analysis process, including coding and thematic analysis.

To analyze the data collected for this study, the researchers conducted thematic analysis to uncover the themes of the study. Thematic analysis allows the researcher to discover essential themes and patterns to answer the research question (Yin, 2018). In this process, the researchers reviewed each interview summary and highlighted the critical themes discovered. After the identification of each interview summary, an Excel worksheet is used to record and organize all common themes. The last step in the analysis is to correlate the themes with the 
prior studies and literature to establish the credibility of the findings (Yin, 2018).

\section{4- Qualitative Research Analyses}

Organizing and coding the data by using Microsoft sheet to categorize the material needed for this study is the main phase in the analysis. The interview transcriptions are first read through, one by one, and relevant quotes and paragraphs are underlined (step 1). Pieces of text are cut out and pasted into separate Word documents, depending on the predetermined theme(s) the content covers (step 2). The themes are then reviewed and additional themes are added if needed (step 3). Example quotes are picked out, and the correspondence between the strategies and the theoretical background is discussed (steps 4 and 5). This section summarizes the themes that emerged with the supporting quotes and breakdown assumptions.

In this study, the researchers reached saturation level after interviewing twenty prospective travelers. Code names were used to ensure confidentially and the privacy of the participants: P1, P2, P3, P4, ... and P20. The following table (Table 2) illustrates the socio-demographic characteristics of the interviewees

Table 2: The Interviewees Socio-demographic Profile

\begin{tabular}{|c|c|c|c|c|c|}
\hline Participant & $\begin{array}{c}\text { Country } \\
\text { Residence }\end{array}$ & Gender & Age & $\begin{array}{c}\text { Marital } \\
\text { Status }\end{array}$ & Occupation \\
\hline P1 & Egypt & Female & Late 20's & Single & Clerk \\
\hline P2 & Egypt & Female & Late 20's & Single & Clerk \\
\hline P3 & UAE & Male & Late 30's & Single & MNC employee \\
\hline P4 & KSA & Female & Early 30's & Single & $\begin{array}{c}\text { Real-estate } \\
\text { Broker }\end{array}$ \\
\hline P5 & China & Male & Early 30's & Married & Foreign teacher \\
\hline P6 & China & Female & Early 30's & Single & Foreign teacher \\
\hline P7 & China & Male & Early 30's & Single & Foreign teacher \\
\hline P8 & France & Female & Late 30's & Married & Marketer \\
\hline P9 & USA & Female & Late 30's & Married & Administration \\
\hline P10 & USA & Male & Late 30's & Married & Finance \\
\hline P11 & UK & Female & Late 30's & Married & College Lecturer \\
\hline P12 & UK & Male & Early 30's & Single & College Lecturer \\
\hline P13 & USA & Male & Early30's & Single & Administration \\
\hline P14 & UAE & Male & Early 30's & Single & Finance \\
\hline P15 & Serbia & Female & Late 30's & Single & House wife \\
\hline P16 & Serbia & Male & Late 30's & Single & Self employed \\
\hline
\end{tabular}




\begin{tabular}{|c|c|c|c|c|c|}
\hline P17 & $\begin{array}{c}\text { South } \\
\text { Africa }\end{array}$ & Male & Late 30's & Married & Gold mining \\
\hline P18 & KSA & Female & Late 20's & Single & Foreign teacher \\
\hline P19 & KSA & Male & Late 20's & Single & Foreign teacher \\
\hline P20 & Portugal & Male & Late 20's & Married & $\begin{array}{c}\text { Post grad } \\
\text { Student }\end{array}$ \\
\hline
\end{tabular}

\section{Theme One: Citizens are living, buying, and thinking differently.}

The COVID-19 pandemic hit citizens unexpectedly and rapidly, changing their standpoints towards many issues in their lives. Citizens are living, buying, and thinking differently. Each participant in this study mentioned various new changes that have occurred in their life.

- "When the pandemic first hit, the feeling of anxiety, fear and discomfort was the commonly held emotion among my network circle" (P1).

- "I'm panicked of the economic impact of COVID-19 than for health matters" (P2).

- "I stopped shopping excessively. I was considered a shopaholic. Now, my priorities have become centered on the most basic needs" (P6).

- "Currently, due to curfews and business restrictions, I know a lot of local businesses that are impacted financially. I'm trying to be a Good Samaritan, so I am beginning to "buy local. I rarely used to do that" (P7).

- "I no longer pray in public places or mosques. It feels strange and odd, especially during Friday mornings prayer times" (P10).

- "I am becoming tech savvy. I am online for everything - work, grocery shopping, exercise, kids school assignments, and I am even watching cooking videos" (P10).

- "I am working from home as the company I am employed at is encouraging remote work. I now have weekly tasks to deliver. They are strict in deadlines because they don't want employees to goof off at home and say they are working. I have not worked remotely before" (P15).

- "I am beginning to see that individuals are becoming cooperate with and caring for one another during crises." (P20). 


\section{Theme Two: Citizens are striving to adapt to a new normal.}

As the COVID-19 crisis continues, many countries have decided to begin to reopen due to economic reasons. The participants in this study explained that they are worried that this is happening, particularly because a cure is not found. Thus, they have not returned back to their normal routines. They still prioritize social distancing. According to the interviews, people across the globe are afraid as they strive to adapt to a "new normal". To survive isolation, citizens are using digital technologies to connect, learn, work, and play-and they will continue to. Like this, the behaviors that were forced upon them will continue along after the post COVID-19 pandemic era.

- "I have embraced digital technology the past couple of months. It eased my way of living and supported all aspects and concerns of isolation" (P3).

- "I believe that the ways in which people spend their leisure time changed because of the outbreak and related social distancing measures. These habits are likely to be sustained" (P4).

- Since I was forced to isolate myself from society to prevent the spread of the virus, I began to see different options to entertain myself at home instead of going to the local coffee shop. I became fond of streaming movies/ shows with my wife.I now feel that family bonding is important and truly pleasurable" (P5).

- "I plan to continue watching more news after the outbreak, and I will continue to prioritize more time with family". (P10).

- "Working remotely has proven to be more productive. Accordingly, I wish to work more from home until the pandemic is truly over" (P13).

- "I have now learned that technology is primary tool to living in 2020. I have downloaded many applications that are useful for daily life practices. I will continue to use and download more new and practical apps related to entertainment, news, health and education. (P14).

- "Technology is changing the way people are living their lives. It has become engaging with consumers and has improved experiences." (P16). 


\section{Theme Three: COVID-19 pandemic reduced-contact channels to get goods/ services.}

Before the pandemic occurred, people loved outdoor and social distractions. People now recognize the value of their out-of-home activities. For example: "dine at restaurants and sit in cafes" (P5); "shop outside the home for non-necessities" (P10); "get together with friends and family" (P12); "spend time in crowded outdoor venues" (P13); "visit hair or nail salons" (P14); "strolling randomly in a shopping mall" (P15)"; "going to work with public transportation/ ride-sharing services while listening to the morning radio station"; "going to Friday prayer service and after prayer socialize with the neighbors" (P17); "traveling and taking adventures, whether it is local or international destinations." (P20)

Now several weeks into reopening, many citizens do not feel comfortable. They do leave their home for a wider range of activities. But, they say it's not the same. "When I go out on the street, it's not crowded, I mean almost empty. It feels strange. (P10)" "Whenever I go out, I avoid crowded settings and try to keep a physical distance of at least 6 feet from people I don't live with (P17)".

\section{Theme Four: The "endless layover" feeling is stirred by the COVID- 19 pandemic}

Many countries enforced specific comportments, which were obliged by all populations. The obligatory closing of the boarders and citizens' changing behavior (shutting doors and promoting isolation) was needed for the infection rate to plateau and start to come down. Thus, all the participants that had plans to travel canceled or postponed travel due to government requirements or personal concerns about COVID-19.

- "I will be ready to fly once the government says the virus is abating" (P8).

- "Due to my Salary reduction because of the pandemic, I probably wont be able afford a vacation anytime soon" (P11).

- "I was invited to a destination wedding that was put on hold, then the date was readjusted, and then readjusted again, and again. The 
pandemic doesn't look like it is getting better anytime soon so I think the event will be cancelled (P12)"

- "I actually did future reservation for the holidays right now. But I am thinking of cancelling it. I am concerned about the news surrounding COVID-19" (P20).

\section{Theme Five: Consumers want extra reassurance to resume traveling activities}

25 percent of the participants in this study now believe the COVID-19 crisis will last up to three months; 30 percent believe the crisis will last to six months, and 45 percent believe it will last over six months. Consequently, the participants believe that the global situation currently is precarious, vulnerable, and risky. Traveling plans will be significantly contemplated. The participants in this study were explicit that traveling for work reasons is important financially. "This traveling task is mandatory, it's not a debatable matter" (P3). However, traveling for leisure is questionable. The participants are not enthusiastic to travel promptly. They were hesitant to get on an airplane right now. But, they are optimistic to travel in the future. "I mean, you can hope, and I'm hoping (P16)." The participants gave vigorous rationalizations.

- "I do not feel comfortable making bookings and travel plans for June, July, August" (P1).

- "If you're talking about international travel, I don't think anybody should be planning to go anywhere this year." (P2).

- "I will travel once the virus is under control and efficient systems are in place to restore confidence in travel" (P3).

- "I believe it's not safe to travel now. This crisis is new and not like no other. It's not a natural disaster that made travels fear. If there's a flood or a forest fire, you can see that and take precaution to not be near it. However, COVID-19 crisis is a virus. You can't see it, so we don't know where they are, and that means they could be anywhere." (P5).

- "Just when that might happen is up in the air, yet it could be as soon as early fall or as late as next spring or beyond". (P13). 
- "Right now people are making plans to go to a shopping mall. If they think of traveling, it will probably be domestic. When people get more comfortable, they'll continue to go farther and farther away from home, moving to international destinations." (P15).

- "The the low airfares available nowadays along many routes are tempting, making me think why not take the risk we will bring lots of disinfectants" (P20).

\section{Theme Six: Citizens are waiting for indicators beyond lifted restrictions before regularly engaging in traveling to a specific destination}

In the future, if the participants in this study were to travel during the post era of COVID-19 pandemic, 35 percent would go to the Middle East, 25 percent would go to Europe, 20 percent would go to Africa, 15 percent would go to Asia, and 5 percent would go to America. The selections of the destinations were based on the participants concern about the news surrounding COVID-19 in the area and the country's reactions, regulations, and system focus to the current events.

During the interviews, the participants expressed that they want extra reassurance to resume traveling outside their homes. Finding a vaccine is great motive to travel again. However, for now, many individuals want the endorsement of medical authorities and the implementation of visible safety measures found in hotels, stores, parks, restaurants, sightseeing sites, and other indoor/outdoor spaces. Thus, ongoing emphasis on cleaning and safety is essential.

- "When I see a country's leader promoting compassion and empathy (along with the nation's security) among its citizens, it makes me pleased and respect the nation further". (P4).

- "A nation should prioritize cleaning and sanitization; and enforcing the usage of masks and physical distancing, and barriers." (P6).

- "We live in a world in which we need to share responsibility. A Nation that is selfless and giving is a leader during this crisis." (P12).

- "In times of emergency, providing empathy, kindness and compassion to our fellow citizens is the single most important factor in surviving 
the initial stages of disaster, limiting suffering, protecting the vulnerable, and quickly recovering in the aftermath of the crisis." (P16).

- "This epidemic is bringing out the best and worst in countries. I believe that America, before the pandemic was attractive in all aspects - tourism, business, health, etc. During the pandemic it is at its worst. We are witnessing high number of victims, hostility, and violence stoked by racism and xenophobic beliefs". (P18).

- "I would prefer to travel near my home country. I still feel that countries are not back to "regular" out-of-home activities." (P19).

- "I would travel to china believe it or not. With restrictions lifting, the people there are increasingly venturing outside their homes for select categories of activities. The country has witnessed a sharp decline in victims." (P20).

\section{Theme Seven: Domestic tourism is expected in the coming period}

The interviewees settled that coronavirus is impacting the travel plans of everyone. In each country, citizens see that nations' government officials provide frequent changes to where people should and shouldn't visit. Countries are closing border. In addition, the sites where people congregate are closing. Thus, there are limited options to travel to. An interviewee mentioned that: "Welcome to the age of adaptivity. As the world tries to conquer the COVID-19 pandemic crisis, people who want to travel need to apply a new perspective supporting isolation destination" (P20). The interviewees believe and accept that shutdowns and travel restrictions are now common and immediate to combat future pandemics. The interviewees are not encouraged to travel far from home because of this instability. For example, an interviewee was saying that: "we don't know what's going to happen with future flights, will there be a plane or will it be postponed till demands are high. However, we know that anytime we want to go out and break this routine of life, we are able to get in the car and drive for three hours and have our own adventure for a known duration, lets say for two weeks and then come back home" (P16). Thus, when the interviewees were asked where and how would they actually travel once they are willing to hit the road again, the 
majority assumed domestic travelling in various forms. They gave illustrations such as:

- "Before I travel to any place, I will check the victim rates. If I were to travel, a road trip to a national park or attraction in the neighboring region is my preferred choice these days. I don't want to travel by plane. Social distancing is difficult on crowded flights, and you may have to sit near others, sometimes for hours. That is not safe." (P1)

- "A week-long stay at a sanitized vacation rental property nearby". (P2).

- "Any close-by location or facility that is insured just in case if closure happens suddenly. I don't want to loose financially any more due to travel plans. (P5)

- "Airbnb is the most suitable approach for accommodation. I believe it would be cleaner and more isolated than a hotel. I don't want to encounter people." (P8).

- "The question on my mind will be 'what are resorts doing to make us feel safe? "Depending on their security policy, I will begin to travel." (P12).

- "I think we're going to book villas and private homes to avoid crowded experiences." (P15).

- "I will not in the coming months stay in a Hotel. Hotels have a lot of turnover of guests, a lot of volume, a lot of people at check-in and check-out." (P16).

- Air travel requires spending time in security lines and airport terminals, which can bring you in close contact with other people and frequently touched surfaces. So I will avoid flights when traveling to other cities in my country" (P17).

- "I want to travel anywhere! But I will do my precautions. For example, I will bring enough alcohol-based hand sanitizer, a face covering to wear in public places, and my own prepared food and water for your trip". (P19).

Based on the responses of the interviewees, people are precautious of social distancing. It's become their new way of life. They fear traveling to 
far places because of the dynamic current events and the unstable regulations that exist in countries, which are out of their hand. Based on the replies, if the person decides to travel, domestic traveling is selected, and the accommodation and transportation facilities chosen are limited to access of people (if not privately owned). They seek ways to travel that will allow them to avoid the large-scale outbreaks of the virus.

\section{Theme Eight: Hit the brakes on marketing and promote values of humanity}

Based on the responses of the interviewees in the previous questions, the COVID-19 pandemic has left people in a distressing state, limiting their traveling activities and increasing their hygiene precautions. In addition, the interviewees indicated that they are obeying the governments and local authorities that have requested people to go under quarantine and exercise isolation in order to reduce the Covid-19 spread. These guidelines have discarded people's traveling plans and locked them in their houses with worry and fear. As the numbers of victims and deaths increases due to the virus, people are becoming pessimistic. The interviewees indicated that the world is disheartening these days and all citizens are suffering one way or another. They specified that:

- "We are already seeing high levels of unemployment due to lockdown measures to control transmission of the virus." (P7).

- "My company has cut my salary. So, Im not getting paid as much as I used to. This makes me rethink my spending habits." (P9).

- "People are learning that social deprivation determines health outcomes." (P10).

- "The virus will impact the global economy, geopolitics and our societies." (P17).

- "The continued stress on people's wellbeing will be felt by people worldwide and will create substantial societal consequences for the long term." (P20).

Consumer behaviors are changed. Global consumer spending decreased every week. An interviewee stated that: "In the last two weeks of April and early May, I haven't purchased any unnecessary products. I believe 
we have to be ready cautious of how we spend our money. Even if we are not finically hurt due to this pandemic, others are. So, it would be uplifting to help those who are in need." (P5). The researcher noticed from the interviewees that getting back to a pre-COVID-19 era is difficult, at least until there is an effective widely available vaccine and therapeutic drugs. People have a natural fear they feel, which was created by government messages regarding lockdowns, and by the data on infection rates and the sad reality of the numbers of COVID-19 deaths.

During the time of depression, the interviewees believe that any business that promotes their products and services, neglecting what citizens are going through is: "selfish and greedy of the business" (P14). An interviewee explained that: "if travel businesses promote and push out messages that encourage voyage and adventure, it is inappropriate. It goes against what world officials request of citizens. Marketing campaigns that encourage traveling might not be perceived well"(P7). Thus, the researcher requested to know what role, if any, does tourism promotion and marketing have at a time when the appetite to travel is low. The interviewees indicated that there is a strong attraction towards the movement of spreading compassion. They clarified:

- "Businesses in all fields should be concerned with the wellbeing of citizens, staff and consumers." (P1)

- "Corporate social responsibility should be priority to businesses now. Good deeds that are taking place today will create a positive image in the minds of people that will last once this pandemic is over." (P3)

- "Nations nowadays should invest in operating in ways that enhance society and the environment, instead of contributing negatively to them." (P5)

- "Philanthropy and volunteer efforts from leaders of a nation can benefit society while boosting their brands." (P6)

- "Social and community activities can help forge a stronger bond between a nation and its citizens; boost morale; and help people feel more connected with the world around them. If a country is known to be charitable to its people, it will trigger word of mouth that spreads globally, impacting its image in the eyes of citizens worldwide."(P13) 
- "Nations should promote compassion leadership. This I believe is significant to create nation brand these days. Compassionate leadership is caring and building a culture in which offering assistance in alleviating suffering is not only appropriate, but should be the norm of today."(P17)

- "Seeing inspirational acts is key - examples of people giving support to others in their communities even in the face of social-distancing, quarantine and fear is attractive in my eyes. It makes a nation look civilized." (P18)

- "I believe we should show how the world is one and all nations are together - the world sharing responsibility for and with one another." (P20)

According to the discussion in the interviews, pausing marketing efforts that support the idea of "traveling and taking adventures now" deems appropriate. The interviewees expressed that they will respect destinations that communicate the importance of the safety of citizens. The interviewees believe that humanitarian acts that are initiated in nations can attract them to a country these days. Thus, the researcher concluded that compassionate management of a nation is a significant element to promote globally. Humanitarian activities are much more than just a feel-good add-on to a nation's image. It has become a prerequisite among leading nations that wish to direct their people and country towards sustained progress and a better future.

\section{Theme Nine: The Virus Changed the Way people use the Internet, rising in-home media consumption}

Communicating to the public is deemed necessary to build an image. Thus, it is vital to choose the right medium to communicate to the potential travelers about your nation. According to the interviewees, the COVID-19 pandemic has left people social distancing. Thus, many of their daily physical activities have switched to online entities with the help of digital technology. People are shopping, working, studying, exercising and entertaining themselves through online platforms, creating high usage of Internet. The discussions provided support that: "People plan to leverage online behaviors across many categories in the near future" (P3). "People acceptance of digital solutions for online shopping is 
growing in countries" (P8). Thus, the researcher concluded that there has been adoption of digital activities and it continues as consumers adjust behavior.

- "During my quarantine, I am in front of my computer all the time, using various applications. Also, I have become a big enthusiast of Netflix." (P9)

- "I have taken up new ways to learn, work, entertain myself, acquire essentials and non-essentials goods and services, connect with others, and increase wellness through the Internet while at home". (P11)

- "Usage of online streaming, personal video chats, and videoconferencing for work has increased rapidly among the people I know" (P14)

- "I did not stop my exercising training that I used to do at the gym because the online fitness attracted me to continue on my healthy lifestyle." (P19)

- "Sadly, during quarantine my phone usage rate (screen time) is high. I am spending a lot of time on social media while I am at home. Its addicting. I get current events on it; I am able to communicate to the people I love; I am able to play games." (P20)

The researcher asked the respondents, when it comes to leisure at home, what medium is influential these days to get your attention. The majority said: Facebook/ Messenger (98\%), YouTube (85\%), Netflix (73\%), zoom (45\%), television (43\%) and other movie-streaming applications (69\%). Thus, the researcher concluded that people are seeking out entertainment on streaming services like Netflix and YouTube, and looking to connect with one another on social media outlets like Facebook. People are spending their day home with computers, tablets, and smartphones close at hand. Thus, if businesses are to communicate to people, they will reach them effortlessly online. This makes nontraditional media popular during the COVID-19 era. Consumers globally intend to continue using many of these activities after the COVID-19 crisis passes. According to the responses the interviewees gave, nontraditional media has progressed more than the traditional media. 


\section{5- Discussion and Conclusion}

The main objective of this paper was to explore how nations can use nation branding during the COVID-19 pandemic to promote optimism in order to stimulate tourism when the peak of the crisis is over. The research sought to answer the following research question: what nationbranding strategies can be used to aid nations in promoting future tourism demand? The research conducted semi-structured interviews with 20 potential tourists from different nations (people who enjoy to travel and seek to travel once the COVID-19 crisis passes). The interviews contained three main key areas: (1) what are citizens' standpoints and perceptions regarding the COVID-19 pandemic impact on their lives? (2) What are the expected tourism behaviors found among individuals? (3) How should businesses promote nation during the post COVID-19 pandemic era?

According to the interviews, nine main themes emerged: citizens are living, buying, and thinking differently; citizens are striving to adapt to a new normal; the COVID-19 pandemic reduced-contact channels to get goods/ services; the "endless layover" feeling is stirred by the COVID-19 pandemic; consumers want extra reassurance to resume traveling activities; citizens are waiting for indicators beyond lifted restrictions before regularly engaging in traveling to a specific destination; domestic tourism is expected in the coming period; hit the brakes on marketing and promote values of humanity; the virus changed the way people use the Internet, rising in-home media consumption. These outcomes deemed supporting to prior studies.

In conclusion, this study developed empirical evidence supporting that coming nation's campaigns should take place on social media more than any other media due to high usage rate of various citizens worldwide; coming nation's campaigns need amendment to attract future visitors because a country's pull factors, the attractiveness of a destination's beaches, recreation facilities and cultural attractions isn't of priority among potential tourist now; Nations worldwide should focus on compassion and humanity activities and publicizing them to gain citizen support; domestic tourists can aid future international tourists to come visit the country through their positive word of mouth on social media. 
With these findings, the researchers developed academic and practical contribution in regards to how nations can use branding to build their image during the COVID-19 pandemic to promote optimism in order to stimulate tourism when the peak of the crisis is over. The below figure (Figure 1) illustrates the proposed conceptual framework that can aid practitioners and future research.

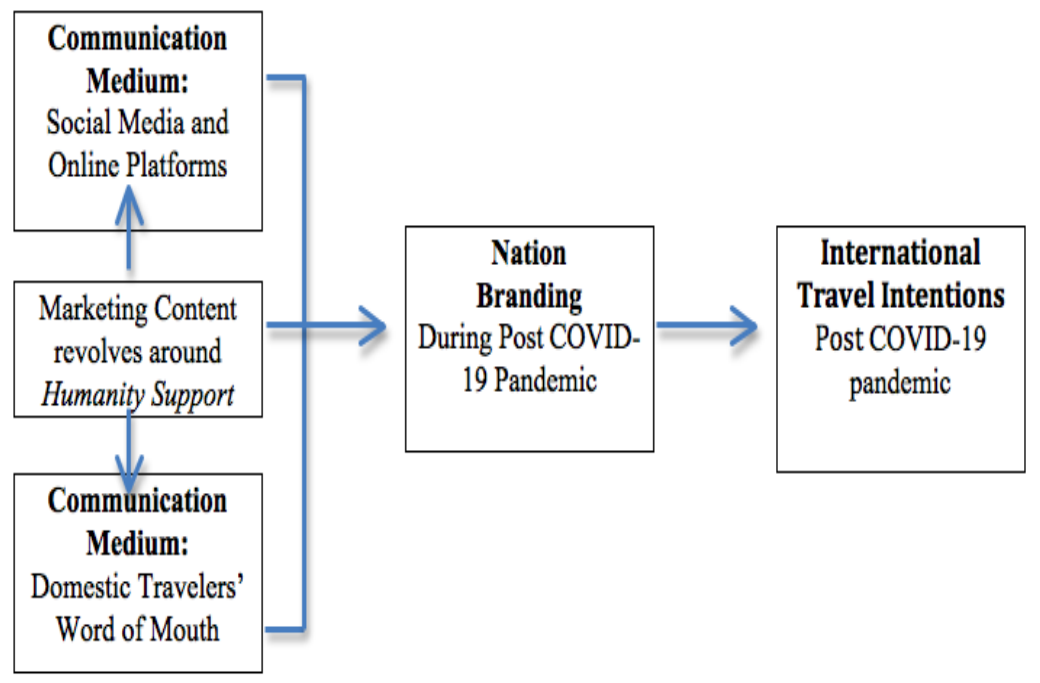

Figure 1: Proposed Conceptual Framework

\section{5-1 Comparison with Previous Studies}

According to the outcomes of the interviews, people are drawn back to the idea of traveling in the current events. Thus, promoting adventure and excitement during a crisis is neither suitable nor fitting to the global status. Consequently, the tourism marketing and nation branding has been disturbed severely. What is happening to this industry during the COVID-19 pandemic has been explained before by prior studies. According to studies, when crises hit, it usually influence the financial structure and fame of organizations negatively (Edworthy et al., 2015). Organizations' survival and achievement of their goals mostly depend on their adaptation to the new-fangled environment (Civelek et al., 2016).

Prior studies explained that during crisis, organizations stress because they are obligated to change their goals, which have been structured in accordance with their long-term strategies (Parnell, 2015). Moreover, depending on the magnitude of the crises, organizational strategies may 
need to be reviewed completely (Parnell, 2015; Hermann, 1972). This is what the tourism industry is facing now (Fortune, 2020). According to the results of this study, the global outbreak of the COVID-19 virus has a major impact on travel. Consequently, the industry needs to develop a plan of the necessary actions to ensure the survival and future recovery of the tourism market. In this study, the interviews revealed that when it comes to traveling in the future, the motives for traveling are no longer related to pull factors, the attractiveness of a destination's beaches, recreation facilities and cultural attractions. Thus, a nation image and branding strategies need amendment to attract future visitors.

According to studies, marketing activities are essential to building a brand and create awareness (Kotler and Armstrong, 2018). In tourism, destinations should increase advertisements, wanting to keep top of mind awareness with travelers who may be planning future trips (REFERECNE). However, this study's empirical evidence showed that citizens think it's inappropriate to promote traveling now. Hence, a theme that emerged in this study was: "hit the brakes on marketing and promote values of humanity." Accordingly, the outcome of this study supports Coombs (2009) research that declared that people during crisis are more compassionate, caring, and gentle during a crisis. This study developed empirical evidence that nations should begin to rebrand its destinations not based of pull factors, but the pull factors (intrinsic stimuli) about humanity and positive spirit building in a community. The best way to do this is by creating content that can be for organic channels like blogs and social media. Research support that communication is important to provide appealing information and prevent negative public opinion about the institution (Civelek et al., 2016; Parnell, 2015).

\section{5-2 Research Contribution}

This study provides both academic and practical contribution. This study developed empirical evidence that contributes knowledge, filling in the academic gap found in literature. According to prior studies, scholars are calling for empirically-based papers that focus on the impacts of COVID19 on markets, destinations, businesses, consumers, destination communities, transit zones and tourism transport (Hall and Cooper, 2020). Thus, this paper contributes to a better understanding of the 
effects of COVID-19 on tourism and the potential travelers opinions on the consumer behaviors. This study contributed practically because the COVID-19 pandemic has had a greater impact on tourism and travel behavior than any disease outbreak in the past (Kaefer, 2020). Thus, with the empirical evidence that emerged in this study, nations, marketers, and tourism practitioners gained insights and ideas regarding developing marketing plan to help take the necessary actions to ensure the survival and future recovery of the tourism market. This study explored the needed marketing content and strategies to combat the negative global conditions and promote nation branding for the post covid-19 pandemic period.

\section{5-3 Research Recommendations}

Based on the practical contributions of this study, the research was able to identify what nation-branding strategies can be used to aid nations in promoting future tourism demand. Since tourism was on hold the past couple of months and since nations' citizens are facing a new experience and implementing different ways of life, it is recommended that nations that brand themselves act as if they are a new start-up again. What attracted prior travelers to their destination, might not seem appealing now to future travelers if security and wellbeing is not in place. So, like marketing new products or product developments, nations and tourism practitioners should seek to understand what the people are looking for when beginning to travel (the needs of the potential tourists), and then encourage them to go on a journey with them. The following paragraph illustrates some recommendations that nations can consider when building the nation brand, encouraging tourism to pick up.

If nations and tourism practitioners manage their campaigns internally, then they can probably build their image adequately among future global travelers. According to the interviewees, they don't want to take the risk to travel far from home just incase there is a "shut-down" like the one that occurred in the past. Besides their health, the interviewees are worried about another entire country lockdowns, border closures, travel restrictions, suspensions of almost all passenger flights, etc., which will lead to tourist being stranded on foreign land. So, it is recommended that nations and tourism practitioners to recommend citizens to support the 
tourism field and take a chance to participate in local traveling, visiting and staying in sites that oblige with the safety standards of the country. When domestic tourism picks up, and locals spread the positive word of mouth about their nation, it can have a ripple effect and encourage international tourists to consider. For example, if local citizens continue to regularly capture and post beautiful visuals of their country's various destinations on social media, it can inspire international tourism to consider the nation as an option to travel to once traveling is common.

Results of this study show that citizens feel that marketing to prospective travelers or pushing out messages that encourage traveling is inappropriate. It goes against what world officials' request of citizens. Thus, marketing campaigns that encourage traveling might not be perceived well. Pausing marketing efforts that support the idea of "traveling and taking adventures now" deems appropriate. The interviewees expressed that they will respect destinations that communicate the importance of people's safety by partaking in humanity efforts. Thus, destinations can connect with people, telling the stories of heroes in their communities; citizens efforts to be "guardian angels" to others in time of need; building communities for a better future. These stories matter, now more than ever, and they will be important for morale when a nation is ready to begin to recover. It is recommended that nations to brand themselves this way. They should focus on their websites and social media pages and posting inspirational pictures and messages. And, if a nation and the tourism practitioners are doing great things behind the scenes (corporate social responsibility) in the interest of citizens, this could be considered as a good campaign message. For the immediate future, this is something that will have a positive impact on the minds of potential travelers, encouraging them to support the mission of the destination.

Nations and tourism practitioners can build their image and brand through communicating to individuals online. Hence, it is recommended that practitioners cancel any costly marketing campaigns, such as TV, radio or newspaper and focus on immediate and interactive marketing channels (like social media). By going viral, tourism businesses can still get necessary face time with potential travelers and create a positive image during a time of turmoil. Nations and tourism practitioners should 
keep website up-to-date with the latest travel information as well as any details on what is open, etc.

\section{5-4 Research Limitations and Direction of Future Studies}

This study was a qualitative research. And like any research, various limitations emerged that future studies can improve on. The data in this study involves the collection, analysis, and interpretation of only qualitative data that are not easily reduced to numbers. Thus, the rigor of this study is more difficult to maintain, assess, and demonstrate. The researcher's presence during data gathering might have affected the subjects' responses. Now, after a couple of months passed in the era of Covid-19 pandemic, future studies can seek to select variables from this study and test it through quantitative research approaches. In this study, data was collected from a few individuals so findings cannot be generalized to a larger population. Findings can however be transferable to another setting. So, future studies can increase the sample size to assure reliable outcomes. This study focused on potential tourists worldwide. Future studies can seek to concentrate on separate countries, generalizing results on specific nationalities and then they might do comparison studies. This study sought to explore people's opinion about traveling in general, not towards a specific location. Therefore, future studies can assess the research question of this study on specific countries and/or cities.

\section{References}

Belch, G. and Belch, M. (2018). Advertising and Promotion: An Integrated Marketing Communications. 11th Edition. McGraw-Hill ISBN10: 1259548147.

Gates, B. (2020) The first modern pandemic. Gatenotes Blog:

https://www.gatesnotes.com/Health/Pandemic- Innovation

Blichfeldt, B. (2017). Strategic Communication in Tourism. Centre for Tourism, Innovation and Culture, University of Southern Denmark.

https://www.sdu.dk//media/files/om sdu/centre/c turisme inn kult/tic/tic+talks/tic+talks+no,-d-,+5.pdf. 
Bundy, J.; Pfarrer, M. D.; Short, C. E.; Coombs, W. T. (2017). "Crises and crisis management: Integration, interpretation, and research development" Journal of Management. 43 (6): 1661-1692.

Emre, C.; Çemberci, M.; Eralp, N. (2016). The Role of Social Media in Crisis Communication and Crisis Management. International Journal of Research in Business \& Social Science 5(3), 2016: 111120.

Coombs, T. (2009). Information and Compassion in Crisis Responses: A Test of Their Effects, Journal of Public Relations Research, 11:2, 125-142, DOI: 10.1207/s1532754xjprr1102_02

Dinnie, K. (2008). Nation Branding: Concepts, Issues, Practice: Oxford, UK: ButterworthHeinemann (An imprint of Elsevier).

Edworthy, J.; Hellier , E.; Newbold, L., \& Titchener, K. (2015). Passing Crisis and Emergency Risk Communications: The Effects of Communication Channel, information type, and repetition. Applied Ergonomics, 48(1), 252-262.

Avraham, E. and Ketter, E. (2017). Destination marketing during and following crises: combating negative images in Asia, Journal of Travel $\&$ Tourism Marketing, 34:6, 709718,https://www.tandfonline.com/doi/ful l/10.1080/10548408.2016.1237926?scroll=top\&needAccess=t rue

European Commission (2020). Communication From The Commission Covid-19 Information From European Union Institutions, Bodies, Offices And Agencies Official. Journal of the European Union.

https://eurlex.europa.eu/legalcontent/EN/TXT/PDF/?uri=CEL EX:52020XC0330(02)\&from $=$ EN

Joann, F. (2020). How search insights can help prepare your tourism strategy for domestic recovery. https://www.citynationplace.com/how-search-insights-can-helpprepare-your-tourism-strategy-for-domestic-recovery 
Dirk, G. (2016). Crisis Management in the Tourism Industry. Elsevier Press.

Hall, C.; Michael Hall and Cooper, Chris (2020). Current Issues in Tourism https://think.taylorandfrancis.com/special issues/currentissuesin-tourism-covid-19-and-tourism/

Hermann, C. (1972). International Crises: Insights from Behavioral Research. New York: New York: Free Press. https://www.linkedin.com/pulse/ consumer-age-coronavirusphilip-kotler-world-marketing-summit

Florian, K. (2020). Corona Pandemic: What it Means for Place Branding Community. The Place Brand Observer. https://placebrandobserver .com /what-corona-pandemicmeans-for-place-branding/

Pauline, K. and Geoffrey, W. (2013). Diplomacy in a Globalizing World: Theories and Practice. New York: Oxford University Press. 354.

Kotler, P. (2020). The Consumer in the Age of Coronavirus. World marketing Summit.

Calderwood, L. and Soshkin, M. (2019). The Travel \& Tourism Competitiveness Report 2019 Travel and Tourism at a Tipping Point. The World Economic Forum. ISBN-13: 978-2-940631-01-8

Lenhart, A. and Duggan, M. (2014). Internet \& Technology. Pew Research Center https://www.pewresearch.org/internet/2014/02/11/mainreport-30/

Hoek, L. (2020). Human coronaviruses: What do they cause? International Medical Press: Antiviral Therapy, 1-15

Handley, L. (2020). 'Acts not ads': How firms should market themselves during the coronavirus crisis. https://www.cnbc.com/2020/03/27/how-firms-should-marketthemselves-during-the-coronavirus-crisis.html

Mira, M. (2020). Egypt's tourism saw 21\% growth in 2019: UNWTO. Egypt Independent https://egyptindependent.com/egyptstourism-saw-21-growth-in-2019-unwto/ 
Minos-Athanasios Karyotakis, Matinakiourexidou, \& Nikos Antonopoulos (2019). Media and YouTube Appeal in Social Movement Mobilization: The Case of Anti-Tourism Incident. Media Watch 10 (3) 687-701,

Negm, E. and Elsamadicy, A. (2017). Investigating Various Motivational Elements That Impact Wedding Destinations (Event Venue) Selections. International Journal of Management and Applied Science, ISSN: 2394-7926. (3)3

Wally, O. (2005). "Making a National Brand". In Melissen, Jan (ed.). The New Public Diplomacy Soft Power in International Relations. New York: Palgrave Macmillan. 169-179.

Parnell, A. (2015). Crisis Management and Strategic Orientation in Small and Medium-Sized Enterprises ( SMEs) in Peru, Mexico and the United States. Journal of Contingencies \& Crisis Management, 23(4), 221-233.

Pew Research Center (2018). Publics globally want unbiased news coverage, but are divided on whether their news media deliver. Retrieved from http://www.pewglobal.org/2018/01/11/peoplein-poorer-countries-just-as-likely-to-usesocial-media-for-newsas-those-in-wealthier-countries/

Ngondo, P. (May 2019). An Exploratory Study: Digital and Social Media Use by Zimbabwean Public Relations Practitioners. Public Relations Journal (12) 3.

Parupalli, R. (2019). The role of English as a Global Language. Research Journal Of English (RJOE) (4) 1, 2019 www.rjoe.org.in An International Peer-Reviewed English Journal ISSN: 2456-2696

Peter, S. (2014). How do People React in a Pandemic?. The Nieman Foundation for Journalism at Harvard University. https://nieman.harvard.edu/wpcontent/uploads/podassets/microsites/NiemanGuideToCoverin gPandemicFlu/CrisisCommunication/HowDoPeopleReactInAPa ndemic.aspx.html 
Seeger, M. and Sellnow, L. and Ulmer, R. (1998). Communication, organization, and crisis. Communication Yearbook. 21: 231275.

Smart Insights (June 3, 2018). Global social media research summary. Retrieved from https://www.smartinsights.com/social-mediamarketing/social-media - strategy/newglobal-social-mediaresearch/

Marcin, S. (2019). A decade on from the crisis Main responses and remaining challenges. EPRS | European Parliamentary Research Service

UN News (2020). Tough times for tourism, but UN travel organization predicts holiday traffic will return. https://news.un.org/en/story/2020/04/1062022

UNWTO - World Tourism Barometer, (2019). International tourism growth continues to outpace the global economy. https://www.unwto. org/international-tourism-growthcontinues-to-outpace-the-economy

UNWTO - World Tourism Barometer, (2020). Only through historic transformation can global tourism beat COVID-19. https://www. euractiv.com/section/economy-jobs/opinion/only-throughhistoric-transformation-can-global-tourism-beat-covid-19/

Chen, W. and Mrkaic, M. and Nabar, M. (2019). The Global Economic Recovery 10 Years After the 2008 Financial Crisis. nternational Monetary Fund.

file:///Users/eimannegm/Downloads/WPIEA2019083.pdf

Huang, Y. and Tseng, Y. and Petrick, J. (2008) Crisis Management Planning to Restore Tourism After Disasters, Journal of Travel \& Tourism Marketing, 23:2-4, 203-

221, DOI: $\underline{10.1300 / J 073 v 23 n 0216}$ 
إستكشاف المحتوى والإستراتيجيات التسويقية اللازمة لمكافحة الظروف العالمية السلبية وتعزيز العلامة التجارية للدولة لفترة ما بعد وباء كورونا المستجد (COVID_19)

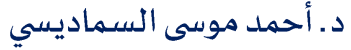

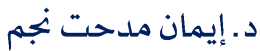

ملخص البحث باللغة العربية

أثر تفشي-جائحة كورونا على الدول والشـركات في صـنـاعة السـياحة اسـتكشـفت هذا البحث كيف يمكن للدول اسـتخدام

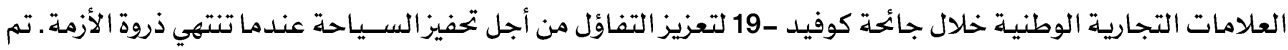

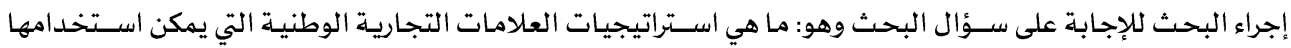

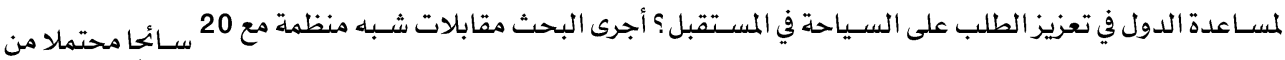

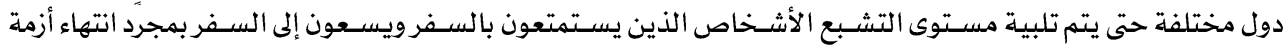

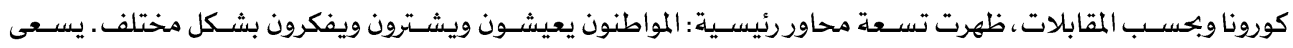

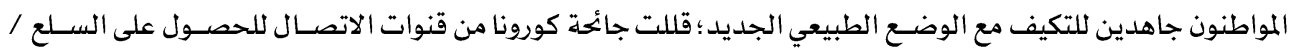

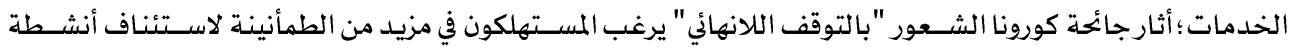

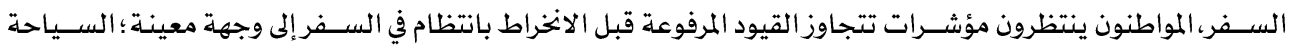

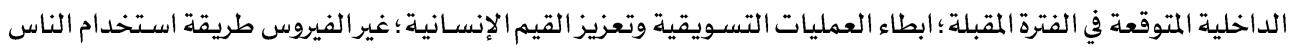

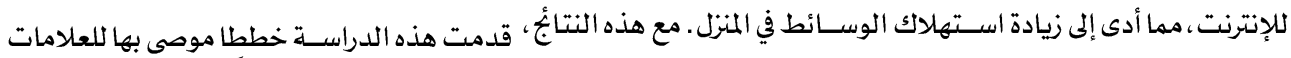

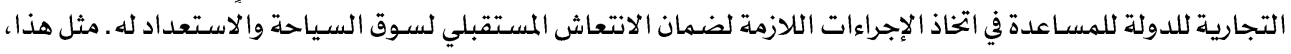

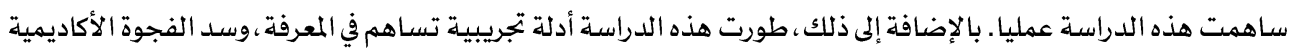

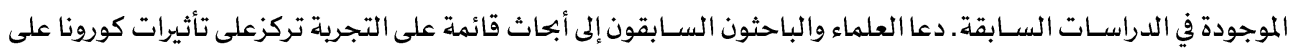

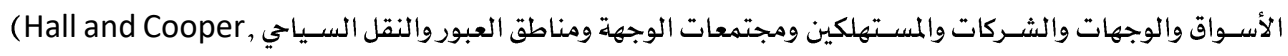

الكلمات الدالة: سلوك المستهلك، العلامة التجارية للدولة، وسائل التواصل الاجتماعي ، التسويق السياحي.

\title{
Suggested Citation according to APA Style
}

Negm, E. M. and Elsamadicy, A. M. (2021). Exploring the Needed Marketing Content and Strategies to Combat the Negative Global Conditions and Promote Nation Branding for the Post COVID-19 Pandemic Period. Journal of Alexandria University for Administrative Sciences, Faculty of Commerce, Alexandria University 58(2), $91-126$. 